НАУКОВИЙ ВІСНИК

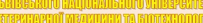

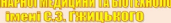
tific messenger af this

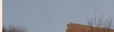
2 11 MIMN Том 21 № 92 2019

\section{Науковий вісник Дьвівського національного університету} ветеринарної медицини та біотехнологій імені С.3. Гжицького. Серія: Харчові технологіі

\author{
Scientific Messenger of Lviv National University \\ of Veterinary Medicine and Biotechnologies. \\ Series: Food Technologies
}

ISSN 2519-268X print

https://nvlvet.com.ua/index.php/food

UDC 637.3

\title{
Improvement of technology of curd products with succade from pumpkin
}

\author{
N.B. Slyvka, O.Ya. Bilyk, O.R. Mikhailytska, V.O. Nagovska \\ Stepan Gzhytskyi National University of Veterinary Medicine and Biotechnologies Lviv, Ukraine
}

Article info

Received 16.09.2019

Received in revised form 14.10.2019

Accepted 15.10.2019

Stepan Gzhytskyi National University of Veterinary Medicine and Biotechnologies Lviv, Pekarska Str., 50, Lviv, 79010, Ukraine.

Tel.: + 38-067-275-37-25

E-mail: slyvkanat@ukr.net
Slyvka, N.B., Bilyk, O.Ya., Mikhailytska, O.R., \& Nagovska, V.O. (2019). Improvement of technology of curd products with succade from pumpkin. Scientific Messenger of Lviv National University of Veterinary Medicine and Biotechnologies. Series: Food Technologies, 21(92), 47-52. doi: 10.32718/nvlvet-f9209

The purpose of the work was to improve the technology of multicomponent milk and protein products curd products with functional and technological components - pumpkin succades, the use of which will allow to increase the biological value and stability of quality indicators of production. Succades are confectionery made from whole or sliced fruits, cooked with sugar, dried or sugar-coated or glazed. Production of succades from local cheap carotene containing raw materials, such as pumpkin, allows to expand the range of vegetable succades of domestic production. The experimental part of the work was performed at the Department of Milk and Dairy Technology of Stepan Gzhytskyi National University of Veterinary Medicine and Biotechnologies Lviv. The research included the development of technology of succade of pumpkin and lemon balm, the choice of ways to make them at the optimum stages of the technological process, the improvement of curd mass technology, the development of their formulations, the study of the quality of the finished product. Raw materials used in the work comply with the State Standard of Ukraine and the requirements of other regulations in Ukraine. The study of a complex of indicators of the chemical composition of pumpkin succades indicates their high nutritional value. On the basis of literature and experimental studies, three variants of formulations of curd masses of high biological value have been developed. Pumpkin succades technology has been developed that has excellent organoleptic characteristics due to the preservation of color, taste of native raw materials and high nutritional value. Technology has been improved and technological parameters of curd production are described. In order to implement the developed technology in the shops for the production of new dairy products at the dairy enterprises it is not necessary to carry out the modernization or reconstruction of production. Experimental studies have determined the optimal dose of pumpkin succades, which is 50-100 kg. The basic physicochemical indices of curd products that meet the requirements of regulatory and technical documentation are investigated.

Key words: curd products, succades, pumpkin, technology, receipt.

\section{Удосконалення технології сиркових виробів 3 цукатами 3 гарбуза}

\author{
Н.Б. Сливка, О.Я. Білик, О.Р. Михайлицька, В.О. Наговська
}

Львівський національний університет ветеринарної медицини та біотехнологій імені С.З. Гжиџького, м. Львів, Україна

\footnotetext{
Метою роботи було удосконалити технологію багатокомпонентних молочно-білкових продуктів - сиркових виробів з функціонально-технологічними складовими - иукатами з гарбуза, використання яких дасть змогу підвищити біологічну иінність та стабільність якісних показників продукції. Цука́ти - ие кондитерські вироби із иілих або нарізаних плодів і ягід, зварених з иукром, підсушених і осипаних иукром або глазурованих. Виробництво иукатів з місцевої дешевої каротинвміщуючої сировини, такої як гарбуз, дозволяє розиирити асортимент овочевих иукатів вітчизняного виробництва. Експериментальна частина роботи виконана на кафедрі технологї̈ молока і молочних продуктів Львівського національного університету ветеринарної медицини та біотехнологій імені С.3. Гжицького. Дослідження включали розроблення технології иукатів із гарбуза з мелісою лимонною, вибір способів їх внесення на оптимальних стадіях технологічного процесу, удосконалення технології сиркових мас, розробку їх рецептур, дослідження якісних показників готового продукту. Сировина, яка використовувалась в роботі відповідала ДСТУ та вимогам іншої діючої в Украӥні нормативної документації. Дослідження комплексу показників хімічного складу иукатів з гарбуза вказує про
} 
їх високу харчову цінність. На основі літературних даних та експериментальних досліджень розроблено три варіанти рецептур сиркових мас підвищеної біологічної цінності. Розроблено технологію иукатів з гарбуза, які відрізняються відмінними органолептичними показниками завдяки збереженню кольору, смаку нативної сировини і мають високу харчову иінність. Удосконалено технологію та описано технологічні параметри виробництва сиркових виробів. Для впровадження розробленої технологї у иехах з виробництва нових молочних продуктів на підприємствах молокопереробної галузі не потрібно здійснювати модернізацію або реконструкцію виробництва. Експериментальними дослідженнями визначено оптимальну дозу внесеня иукатів з гарбуза, яка складає 50-100 кг. Досліджено основні фізико-хімічні показники сиркових виробів, які відповідають вимогам нормативно-технічної документації.

Ключові слова: сиркові вироби, иукати, гарбуз, технологія, рецептура.

\section{Вступ}

Здоров'я людини та відновлення його організму тісно пов'язано з раціональним харчуванням. Сучасний напружений ритм роботи працівників різних галузей, все більша урбанізація життя, підвищення добробуту і зменшення фізичної активності потребують харчування з низькими енергетичними показниками, але високою біологічною цінністю. Стрімкий розвиток хворіб аліментарного характеру вимагає дієтичного харчування. Всі ці фактори призводять до необхідності розширення асортименту функціональних продуктів харчування (Popova \& Barkalova, 2014; Hachak et al., 2017; Nagovska et al., 2018; Slyvka et al., 2018; Hachak et al., 2019).

Улюбленими продуктами щоденного раціону споживачів $є$ кисломолочний сир та вироби 3 нього. Проте необхідність покращення споживчих властивостей, підвищення конкурентоспроможності, забезпечення стабільних якісних показників цих продуктів вимагає раціоналізації складу та коригування традиційних технологій сиркових виробів. Перспективним залишається виробництво багатокомпонентних молочнобілкових продуктів десертного призначення з використанням нетрадиційної сировини рослинного походження та різноманітних харчових добавок (Onopriichuk et al., 2006).

Ефективним способом удосконалення технології сиркових виробів є оптимізація рецептурного складу завдяки додавання цукатів із овочевої чи фруктової сировини.

Цука́ти - це кондитерські вироби із цілих або нарізаних плодів і ягід, зварених з цукром, підсушених і осипаних цукром або глазурованих (Borovskyi et al., 1995). Асортимент цукатів на ринку України обмежений. Переважно використовують фруктово-ягідні цукати закордонних виробників, які мають великий вміст штучних барвників, що знижує їх біологічну цінність. Крім того, вони не доступні широкому колу споживачів внаслідок високої вартості. Тому виробництво цукатів 3 місцевої дешевої каротинвміщуючої сировини, такої як гарбуз, дозволяє розширити асортимент овочевих цукатів вітчизняного виробництва (Zakharenko \& Nepochatykh, 2002; Zakharenko et al., 2003).

Серед овочевих культур, які вирощують в Україні, важливе місце завдяки хімічному складу посідає гарбуз, завдяки своєму складу. Плоди гарбуза - це цілий комплекс таких біологічно активних речовин, як вуглеводи, полісахариди, білки, поліцукри, харчові волокна, вітаміни, органічні кислоти, жирні кислоти, стероли, пептиди, мінеральні речовини. Вони сприяють очищенню організму, покращують виведення шлаків, токсинів, солей важких металів та радіонуклідів із організму (Belinska, 2002; Skvorcov et al., 2010; Erin, 2011).

Використання нетрадиційної сировини дозволяє отримати продукт з високою харчовою та біологічною цінністю, який відповідає положенням раціонального харчування, є мікробіологічно, екологічно нешкідливим і економічно доцільним (Pavlova et al., 2006). Окрім цього, запропонована технологія дозволить розширити асортимент сиркових виробів на споживчому ринку України та інших країн.

Мета роботи - удосконалення технології багатокомпонентних молочно-білкових продуктів - сиркових виробів з функціонально-технологічними складовими - цукатами з гарбуза, використання яких дасть змогу підвищити біологічну цінність та стабільність якісних показників продукції.

Згідно $з$ поставленою метою й робочою гіпотезою про можливість використання гарбуза, треба було вирішити наступні задачі:

- науково обгрунтувати й розробити технологію цукатів із гарбуза;

- обгрунтувати особливості технології сиркових мас із наповнювачами;

- дослідити комплекс показників якості готових продуктів.

\section{Матеріал і методи досліджень}

Експериментальна частина роботи виконана на кафедрі технології молока i молочних продуктів Львівського національного університету ветеринарної медицини та біотехнологій імені С.3. Гжицького. Дослідження включали розроблення технології цукатів із гарбуза з мелісою лимонною, вибір способів їх внесення на оптимальних стадіях технологічного процесу, удосконалення технології сиркових мас, розробку їх рецептур, дослідження якісних показників готового продукту.

Сировина, яка використовувалась в роботі відповідала ДСТУ та вимогам іншої діючої в Україні нормативної документації.

Відбір та готування проб для проведення досліджень здійснювали згідно з ДСТУ4834, ДСТУISO 707, ДСТУISO 5538, ДСТУ4601, ГОСТ26929; готування зразків і розведень для мікробіологічних досліджень - згідно 3 ДСТУ IDF 122C, ГОСТ9225, ГОСТ26668, ГОСТ26669.

Органолептичний аналіз готової продукції проводили за певною кількістю дескрипторів профільним 
методом 3 використанням десятибальної шкали за усередненими даними.

Визначення фізико-хімічних показників сиркових мас проводили згідно з ГОСТ 5867 - масову частку жиру, ГОСТ 23327 - масову частку білка, ГОСТ 3626 масову частку вологи і сухих речовин, ГОСТ3624 титровану кислотність.

Визначення масової частки вологи в сирковій масі здійснювали на приладі Чижової за ГОСТ 3626.

Бактерії групи кишкової палички визначали- згідно $з$ ГОСТ 9225, ДСТУ IDF 73А. Визначання патогенних мікроорганізмів, зокрема бактерій роду Salmonella- згідно з ДСТУ IDF 93A, Staphylococcus aureus- згідно з ГОСТ 30347, Listeria monocytogene sзгідно з ДСТУ ISO 11290-1-2.

Енергетичну цінність розраховували на основі фактичного вмісту в продуктах білків, жирів, вуглеводів.

\section{Результати та їх обговорення}

Для отримання цукатів гарбуз чистять і ріжуть невеликими кубиками. Порізаний гарбуз бланшують 3-5 хв.

Цукровий сироп готували на водному екстракті меліси. Концентрація сиропу 70-71\% Для одержання екстрактів сировину подрібнювали до розміру часток 3 мм, бо при цьому збільшується поверхня частинок сировини і контакту твердої та рідкої фази при екстрагуванні і спостерігається ефективніший перехід екстрактивних речовин в розчин. На швидкість переходу екстрактивних речовин в екстракт впливала температура екстрагенту. Використовували екстрагент воду у співвідношенні суха лікарська сировина і вода як 1:1. Дослідженнями встановлено оптимальну тривалість процесу екстрагування - 60 хв при температурі $60{ }^{\circ} \mathrm{C}$. Подальше збільшення температури вище $60{ }^{\circ} \mathrm{C}$ призводить до руйнування вітаміну С. Екстракт мав світло-оранжевий колір, запах слабкий, приємний трав'яний $з$ нотами лимону, смак слабковиражений, пряний з кислинкою.

Далі у гарячий сироп поміщають шматочки гарбуза. Уварювання сировини ведеться при температурі $60{ }^{\circ} \mathrm{C}$ протягом 3,0-3,5 год до досягнення вмісту розчинних сухих речовин у цукатах 76-77\%. Зварені плоди сушать у сушильних камерах при температурі $45{ }^{\circ} \mathrm{C}$ протягом 4 год. При необхідності обкачують цукром і фасують.

У таблиці 1 наведено органолептичні показники отриманих цукатів.

Таблиця 1

Органолептичні показники цукатів

\begin{tabular}{ll}
\hline \multicolumn{1}{c}{ Показник } & \multicolumn{1}{c}{ Характеристика } \\
\hline Зовнішній вигляд & $\begin{array}{l}\text { кубики прозорі, не зморщені, однорідні за розміром і формою, обсипані цукровою пудрою, не } \\
\text { злиплі }\end{array}$ \\
Консистенція & щільна, не суха, плоди рівномірно проварені, легко розрізаються, без наявності грудочок цукру, \\
& що викристалізувався \\
Запах & приємний, з ароматом меліси лимонної \\
Колір & від світлого до темного жовтогарячого, однорідний за всією масою, прозорий при розрізанні \\
Смак & солодкий \\
\hline
\end{tabular}

Дослідження комплексу показників хімічного складу цукатів з гарбуза свідчить про їх високу харчову цінність (табл. 2).

\section{Таблиця 2}

Хімічний склад сировини і цукатів з гарбуза

\begin{tabular}{lc}
\hline \multicolumn{1}{c}{ Показник, \% } & Цукати з гарбуза \\
\hline Сухі речовини & $82,3 \pm 0,2$ \\
Білки & $0,70 \pm 0,3$ \\
Вуглеводи & $78,8 \pm 0,7$ \\
Зола & $0,56 \pm 0,001$ \\
Енергетична цінність, ккал/100г & $298,5 \pm 5,9$ \\
\hline
\end{tabular}

На основі літературних даних та експериментальних досліджень розроблено три варіанти рецептур сиркових мас підвищеної біологічної цінності, які наведені у табл. 3.

\section{Таблиця 3}

Рецептури сиркових мас м.ч.ж. 6\%, кг на 1000 кг продукту без врахування втрат

\begin{tabular}{lccc}
\hline \multirow{2}{*}{ Інгредіснти } & \multicolumn{3}{c}{ Рецептура } \\
\cline { 2 - 4 } & №1 & №2 & №3 \\
\hline $\begin{array}{l}\text { Сир нежирний з масовою } \\
\text { часткою вологи 80 \% }\end{array}$ & 680 & 730 & 780 \\
Вершки з масовою часткою жиру & & & \\
$50 \%$ & 120 & 120 & 120 \\
Цукати & 150 & 100 & 50 \\
Цукор & 50 & 50 & 50 \\
Всього & 1000 & 1000 & 1000 \\
\hline
\end{tabular}

На основі дегустаційного аналізу відібрано для подальших досліджень рецептуру № 3. Результати досліджень представлені у таблиці 4. 
Таблиця 4

Основні органолептичні характеристики сиркової маси без і з цукатами гарбуза

\begin{tabular}{|c|c|}
\hline Показник & Характеристика показника \\
\hline \multicolumn{2}{|r|}{ Сиркова маса, масова частка жиру 6\% (контроль) } \\
\hline Зовнішній вигляд & Однорідна маса з нерівною поверхнею \\
\hline Структура і консистенція & М’яка, однорідна, мазеподібна, розсипчаста. \\
\hline Смак і запах & Чистий кисломолочний, без сторонніх присмаків і запахів \\
\hline Колір & Білий з кремовим відтінком, рівномірний по всій масі \\
\hline \multicolumn{2}{|r|}{ Сиркова маса з функціональною добавкою, масова частка жиру 6\% (дослід) } \\
\hline & $\begin{array}{ll}\text { №1 } & \text { №2 } \\
\end{array}$ \\
\hline Зовнішній вигляд & Однорідна маса з нерівною поверхнею \\
\hline Структура і консистенція & $\begin{array}{c}\text { Однорідна, гомогенна із рівномірно розподіленими по всій масі цукатами, } \\
\text { при зберіганні не змінюється }\end{array}$ \\
\hline Смак і запах & $\begin{array}{ll}\text { солодкий, } 3 \text { сильно вираже- } & \text { кисломолочний, } 3 \text { яскраво вираженим гарбузовим } \\
\text { ним смаком і запахом гарбуза } & \begin{array}{l}\text { присмаком i приємним ароматом. Смак i аромат } \\
\text { гармонічні. }\end{array}\end{array}$ \\
\hline Колір & Білий, з включеннями оранжевого кольору \\
\hline
\end{tabular}

Діаграма технологічного процесу виробництва сиркової маси з цукатами гарбуза наведена на рисунку 1.

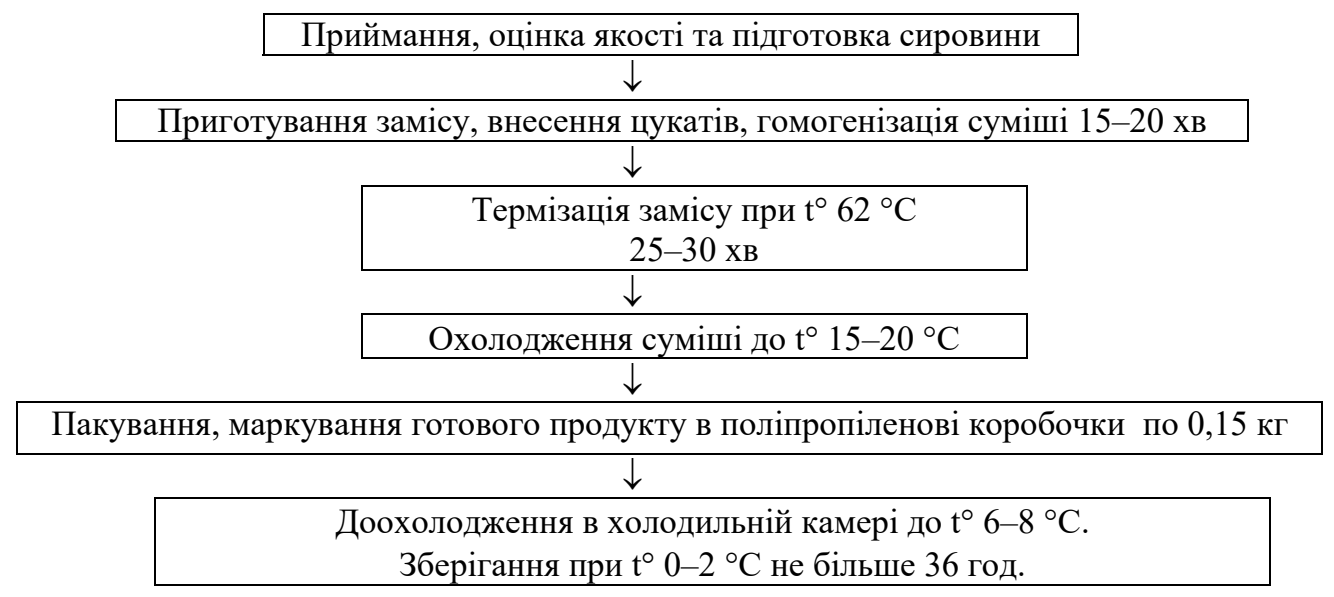

Рис. 1. Технологічна діаграма виробництва сиркової маси з цукатами гарбуза

Сировину, яка поступає для виробництва сирних мас, приймають за масою та якістю, що встановлюють лабораторією заводу. Сировина, яка не відповідає вимогам стандартів, вибраковується. Кисломолочний сир при потребі зачищають 3 вилученням забрудненої частини або шару поверхні, якщо сир змінив свій колір.

Використовують свіжо виготовлений сир з кислотністю не вище $210^{\circ} \mathrm{T}$, масовою часткою сухих речовин 27\%. При необхідності сир перетирають на вальцювальній машині для надання йому однорідної консистенції без грудочок і крупки. Кисломолочний сир повинен бути незамороженим.

Для доведення масової частки вологи в кисломолочному сирі до необхідної, його допресовують за допомогою пресів при температурі в приміщенні не більше $6{ }^{\circ} \mathrm{C}$.

Вершки, зарезервовані при температурі $(4 \pm 2){ }^{\circ} \mathrm{C}$, нормалізують за масовою часткою жиру, підігрівають до температури $65-70{ }^{\circ} \mathrm{C}$. Підігріті вершки гомогенізують при тиску 7,0 та 4,0 МПа на першому та другому ступенях гомогенізації, відповідно.
Цукати після сортування розрізають вздовж ребра на шматки необхідних розмірів за допомогою цукаторізки, шпигорізки або інших приладів.

У змішувачі кисломолочний сир нормалізують вершками, додають підготовлені цукати. Середня тривалість перемішування складає 5-10 хв.

Приготовану суміш завантажують у змішувач установки “Mixter - 2500” для інтенсивного перемішування і гомогенізації суміші. Ця установка складається з резервуара-змішувача 3 насосом, що має гомогенізуючу насадку i резервуара-лоточника для перемішування і термізації продукту. Міксер може підігріватись парою $з$ тиском не більше 0,5 атм. Після перемішування 20-30 хв сирна маса за допомогою насосу із гомогенізуючої насадки подається в пристрій для термізації сирної маси. Термічну обробку проводять при температурі $62{ }^{\circ} \mathrm{C}$ при постійному перемішуванні протягом 30 хв.

Фасування проводять в герметичну тару - поліпропіленові коробочки масою нетто 150 г. У процесі фасування необхідно контролювати дотримання санітарно-гігієнічних умов. Після фасування в холодильних камерах готовий продукт доохолоджують до температури $(4 \pm 2){ }^{\circ} \mathrm{C}$. Готовий продукт зберігають до 
використання при температурі $2 \ldots 6{ }^{\circ} \mathrm{C}$ не більше 10 діб з моменту закінчення технологічного процесу, в т.ч. на підприємстві - не більше 2 діб.

Для впровадження технології на підприємствах молокопереробної галузі не потрібно здійснювати модернізацію або реконструкцію виробництва. Крім того, для ферментації знежиреного молока рекомендуємо використовувати сировиготовлювачі закритого типу 3 подальшим зневодненням згустку з використанням установок барабанного типу або спеціальних фільтрів.

Розроблена технологія дозволяє отримати якісні та цінні в харчовому відношенні сиркові вироби, орга- нолептичні показники яких не поступаються сирковим масам, що виготовлені за традиційною технологією. Розроблені продукти рекомендуються використовувати в дієтичному та лікувально-профілактичному харчуванні.

3 технологічної точки зору важливими $є$ фізикохімічні показники дослідних зразків. До основних фізико-хімічних показників кисломолочного сиру відносять кислотність, активна кислотність, масову частку вологи, сухої речовини, жиру, енергетичну цінність продукту.

Результати досліджень фізико-хімічних показників наведені у таблиці 5.

Таблиця 5

Основні фізико-хімічні показники сиркових мас м.ч.ж. 6\%

\begin{tabular}{|c|c|c|c|c|c|}
\hline \multirow{2}{*}{ Продукт } & \multirow{2}{*}{$\begin{array}{c}\text { Кислотність, } \\
{ }^{\circ} \mathrm{T}\end{array}$} & \multicolumn{3}{|c|}{ Масова частка основних складових, \% } & \multirow{2}{*}{$\begin{array}{c}\text { Енергетична } \\
\text { цінність, ккал/100 г }\end{array}$} \\
\hline & & вологи & сухої речовини & жиру & \\
\hline Контрольний зразок & 124 & 68 & 32 & 6 & 167 \\
\hline Дослідний зразок 1 & 129 & 64 & 36 & 6 & 186 \\
\hline Дослідний зразок 2 & 126 & 66 & 34 & 6 & 174 \\
\hline Дослідний зразок 3 & 123 & 65 & 35 & 6 & 170 \\
\hline
\end{tabular}

3 таблиці 5 видно, що у дослідних зразках знизився вміст вологи на 4,5\% порівняно 3 контролем, а вміст сухих речовин підвищився на 9\%. Це привело до підвищення енергетичної цінності продукту.

Результати досліджень мікробіологічних показників розроблених сиркових мас наведені у таблиці 6.

\section{Таблиця 6}

Мікробіологічні показники сиркових мас м.ч.ж. 6\%

\begin{tabular}{|c|c|c|}
\hline Найменування показника & & Результати \\
\hline БГКП в $0,001 \mathrm{~cm}^{3}$ & & не виявлено \\
\hline Staphilococcus aureus в $0,01 \mathrm{~cm}^{3}$ & & не виявлено \\
\hline $\begin{array}{l}\text { Патогенні мікроорганізми, } \\
\text { числі Сальмонела, } 25 \mathrm{~cm}^{3}\end{array}$ & тому & не виявлено \\
\hline Дріжджі та плісені & & не виявлено \\
\hline
\end{tabular}

Підсумовуючи результати фізико-хімічних та мікробіологічних досліджень, можна стверджувати, що розроблені сиркові маси є безпечними для здоров'я людини та відповідають вимогам нормативнотехнічної документації.

\section{Висновки}

1. На основі літературних даних вибрано природні джерела рослинної сировини, багатої на біологічно активні речовини, а саме гарбуз звичайний, для створення цукатів.

2. Розроблено технологію цукатів з гарбуза, які відрізняються відмінними органолептичними показниками завдяки збереженню кольору, смаку нативної сировини і мають високу харчову цінність.

3. Удосконалено технологію та описано технологічні параметри виробництва сиркових виробів. Для впровадження розробленої технології у цехах з виробництва нових молочних продуктів на підприємствах молокопереробної галузі не потрібно здійснювати модернізацію або реконструкцію виробництва.
4. Експериментальними дослідженнями визначено оптимальну дозу внесеня цукатів з гарбуза, яка складає 50-100 кг.

5. Досліджено основні фізико-хімічні показники сиркових виробів, які відповідають вимогам нормативно-технічної документації.

\section{References}

Belinska, S.O. (2002). Tovaroznavcha kharakterystyka novykh vydiv zamorozhenykh harbuzovykh ovochiv: avto-ref. dys. na zdobuttia nauk. stupenia kand. tekhn. nauk : spets. 05.18.15. Kyivskyi derzh. torh.-ekon. un-t. K., 22 (in Ukrainian).

Borovskyi, V., Ratushniak, V., \& Holinko, O. (1995). Tsukaty $\mathrm{z}$ ovochiv ta fruktiv. Kharchova i pererobna promyslovist, 311, 19-21 (in Ukrainian).

Erin, I.V. (2011). Sortovye osobennosti semennoj i maslichnoj produktivnosti tykvy. Nauchnyj zhurnal KubGAU, 72(08), 12-17. https://cyberleninka.ru/ article/n/sortovye-osobennosti-semennoy-i-maslichnoyproduktivnosti-tykvy (in Russian).

Hachak, Y., Slyvka, N., Gutyj, B., Vavrysevych, J., Sobolev, A., \& Bushueva, I. (2019). Investigation of the influence of cryopowders "broccoli" and "laminaria" on quality parameters of cheese masses of different fat. EUREKA: Life Sciences, 1, 28-35. doi: 10.21303/2504-5695.2019.00839.

Hachak, Y., Slyvka, N., Gutyj, B., Vavrysevych, J., Sobolev, A., Bushueva, I., Samura, T., Paladiychuk, O., Savchuk, L., Pikhtirova, A. (2019). Effect of the cryopowder "Beet" on quality indicators of new curd desserts. Eastern-European Journal of Enterprise Technologies, 1, 11(97), 52-59. doi: 10.15587/17294061.2019.154942.

Hachak, Yu.R., Hutyi, B.V., Benytska, A., Diakun, T., Prystanskyi, R., \& Kinnytska, L. (2017). Vykorystannia krioporoshku "Amarant" v tekhnolohii 
molochnykh produktiv likuvalno-profilaktychnoho spriamuvannia. Naukovyi visnyk LNUVMBT imeni S.Z. $\quad$ Gzhytskoho, 57-62. doi: $10.15421 /$ nvlvet8012.

Nagovska, V.O., Hachak, Yu.R., Bilyk, O.Ya., Gutyj, B.V., Slyvka, N.B., \& Mikhailytska, O.R. (2018). Influence of thistle grist on organoleptic, physicochemical and microbiological parameters of kefir. Scientific Messenger of Lviv National University of Veterinary Medicine and Biotechnologies, 20(85), 166170. doi: $10.15421 /$ nvlvet8530.

Onopriichuk, O.O., Hrek, O.V., \& Potapenko, S.I. (2006). Rozroblennia tekhnolohii kombinovanoho molochnobilkovoho produktu Z roslynnymy inhrediientamy. Tavriiskyi naukovyi visnyk, 43, 92-100 (in Ukrainian).

Pavlova, Zh.P., Parfenova, T.V., Grechkina, Ju.A., \& Pashin, N.N. (2006). Tvorozhnye izdelija s fitokomponentami. Proizvodstvo tvoroga s vysokim soderzhanie suhih veshhestv. Pererabotka moloka, 10, 14-16 (in Russian).

Popova, N.O., \& Barkalova, A.I. (2014). Vykorystannia netradytsiinoi roslynnoi syrovyny pry vyrobnytstvi syrkovykh vyrobiv. Tovaroznavchyi visnyk, 7, 166172. http://nbuv.gov.ua/UJRN/Tvis_2014_7_27 (in Ukrainian).

Skvorcov, D.V., Betin, A.G., \& Tihonov, A.S. (2010). Pererabotka tykvy s sohraneniem pitatel'noj cennosti. Vorcov. Al'manah sovremennoj nauki i obrazovanija, 11(42), 136-137. http://www.gramota.net/materials/1/ 2010/11-2/44.html (in Russian).

Slyvka, N., MyhaylytskaO., Nahovska, V., \& Bilyk, O. (2018). The use of pear fillers in kefir technology. Scientific Messenger of LNU of Veterinary Medicine and Biotechnologies. Series: Food Technologies, 20(90), 63-68. doi: 10.32718/nvlvet9013.

Zakharenko, V., Nepochatykh, T., \& Tomashevska, R. (2003). Tsukaty $z$ harbuziv ta morkvy. Kharchova $\mathrm{i}$ pererob-na promyslovist, 2, 25-26 (in Ukrainian).

Zakharenko, V.O., \& Nepochatykh, T.A. (2002). Deiaki teoretychni aspekty pryhotuvannia tsukativ na osnovi harbuza. Obladnannia ta tekhnolohii kharchovykh vyrobnytstv: Temat. zb. nauk. pr. Donetsk: DonDUET, 2(14), 153-158 (in Ukrainian). 